УДК: 321.74

ТУПАЕВ Андрей Васильевич - старший преподаватель кафедры теоретической и прикладной политологии Южного федерального университета (344090, Россия, г. Ростов-на-Дону, пер. Днепровский, 116; Bio-412@yandex.ru)

\title{
ИДЕОЛОГИЧЕСКОЕ ПРОШЛОЕ И ЛЕГИТИМАЦИЯ ПОЛИТИЧЕСКОГО ПОРЯДКА: ОПЫТ СОВРЕМЕННОЙ РОССИИ
}

\begin{abstract}
Аннотация. Предметом исследования данной работы является легитимация политического порядка в современной России на принципах использования элементов идеологического прошлого. Объектом исследования служат формы легитимации, выработанные с использованием элементов идеологического прошлого, политических традиций и мифов. На основе исследования автор делает вывод, что современный российский политический порядок воспроизводит легитимность, в основе которой находятся актуализированные властью исторические элементы идеологического прошлого.
\end{abstract}

Ключевые слова: легитимность, идеология, идеологическое прошлое, политический порядок, политические традиции, власть

$\mathrm{C}$ пустя 27 лет после распада СССР нельзя не согласиться с утверждением академика РАН Ю.С. Пивоварова, что мы живем в советской посткоммунистической стране [Пивоваров 2011: 54]. Современная Россия перестала быть коммунистической, однако сохранила качества советского общества, организовав новую, деидеологизированную форму социального существования. «Советское» в данном контексте Ю.С. Пивоваров рассматривает как форму русского массового общества и своеобразных процессов урбанизации, которые сводят высокую культуру к примитивизму социальных и политических моделей [Пивоваров 2011: 55-58]. Следовательно, идеологическое прошлое сформировало особый социотип человека, модели управления, ведения хозяйства и легитимации политического порядка, которые сохраняются вне зависимости от институционально-правовой матрицы государства. В Конституции России 1993 г. закреплено, что ни одна идеология не может быть установлена в качестве обязательной и государственной; такое положение предполагает плюрализм идей и ценностей в общественном сознании, невозможность формирования политического порядка с доминированием одной идеологии. Однако конституционными принципами невозможно решить проблему использования идеологического прошлого как инструмента легитимации политического порядка. Зачастую идеологическое прошлое приобретает форму политической традиции, формируется как основополагающий принцип легитимности и воспроизводится посредством идеологем и политических мифов. Существовавшая идеология продолжает влиять на систему ценностей и ориентиров формирования политического порядка не в форме целостной конструкции, а через различные идейные составляющие. Идеологическое прошлое имеет сложные причинно-следственные связи с современными социально-политическими процессами и, формируя дискурс, определяет принципы легитимации политического порядка. Одно из явных проявлений влияния идеологического прошлого заключается в сложности становления либерально-конституционных ценностей, конкурентной экономики и политики, в формировании интереса к традиционным властно-управленческим моделям, национально-исторической идентичности и духовным ценностям.

Для концептуализации идеологического прошлого мы будем основываться 
на синтезе трех понятий: это историческое прошлое, коллективная память и идеология. В концепции французского философа Р. Барта историческое прошлое представляет собой нарративные конструкции, мало связанные с реальными историческими событиями и подчиненные идеологическому дискурсу [Барт 2003: 340]. Следовательно, историческое прошлое - воображаемая конструкция, выраженная в дискурсе настоящего и использующаяся для создания вымышленной репрезентации исторических событий. Понятие коллективной памяти используется в рамках концепции А. Ассман [Ассман 2014]. Теория коллективной памяти, предложенная немецким историком и культурологом, характеризуется междисциплинарностью и носит символический характер. Коллективная память передается из поколения в поколение через символы, ритуалы, памятные даты, мемориальную культуру. История и память - взаимодополняющие понятия: они проявляются друг в друге, исторические события приобретают свойства мемориализации. Коллективная память связана с социальной коммуникацией. Носителем памяти выступает мозг индивида, матрицу воспроизводства памяти задают символические медиаторы. Обращение к историческому прошлому связано с современными проблемами и поиском исторического обоснования существующей социальной реальности. Идеология выполняет ряд важных политических функций. Так, М. Фриден [Freeden 2006] подчеркивает, что когнитивные свойства идеологии выполняют функцию легитимации, интеграции, социализации, упорядочения, упрощения и ориентации действия [Игры... 2016]. Когнитивный подход к идеологиям, предложенный М. Фриденом, следует дополнить лингвистическим пониманием идеологии как системы взглядов и социологическим - как выполняющим функцию господства-подчинения. Согласно Т. ван Дейку, идеологии обнаруживают принципиальное сходство с аттитюдами [Поцелуев, Константинов 2016: 1612]. В дискурсивном измерении это сходство представлено диалогикой «вопрос - ответ»; на когнитивном уровне - структурой «проблема - ее решение»; на социальном уровне - конфликтом интересов [Поцелуев, Константинов 2016: 1610]. Таким образом, идеологическое прошлое представляет собой репрезентацию идеологических процессов в историческом прошлом, включенное в когнитивно-дискурсивную матрицу оценки современного политического порядка.

Ответ на вопрос: «Какое общество мы хотим увидеть в будущем?» - напрямую взаимосвязан с оценками идеологического прошлого и требует существенного теоретического осмысления. Вопрос существования политического порядка тесно связан с легитимностью власти [Булдаков и др. 2011: 58]. Формирование легитимности начинается с определения, какую именно легитимность имеет современное российское государство. Ю.С. Пивоваров выделяет два вида легитимности - историческую и конституционно-правовую. Дополняя друг друга, они создают народный суверенитет, придавая ему релевантность и консенсуальность. Современная Россия по типу своей легитимности кардинально отличается от Российской империи и СССР. Поначалу, следуя конституционному мейнстриму XIX-XX вв., доминирует конституционно-правовая легитимность, т.е. проект конституции сработал вне зависимости от того, осознавало общество или нет исторический компонент легитимности. Конституция 1993 г. позволила связать русскую модель власти и западную модель конституционного устройства. Если говорить об исторической легитимности, которая сформировалась путем объявления Россией себя правопреемником СССР в международных отношениях, можно утверждать, что Россия есть продолжение СССР в содержательно-историческом смысле. Это проявляется в том, что природа современного российского общества не антисоветская, а некая постсоветская стадия развития существовавшего соци- 
ума. Таким образом, конституционно-правовая легитимность была дополнена легитимностью правопреемства России по отношению к советскому периоду, а СССР - по отношению к дореволюционной России и связана с русской системой власти, ценностью величия державы, претендующей на ключевые мировые позиции [Булдаков и др. 2011: 62].

В современной России фактически произошел отказ от выборной сменяемости власти, реформирована модель избирательной системы, усилены теневые и неконституционные институты. Все это привело к уменьшению действия правовой легитимности. Конституция переместилась на периферию реальной политики. Легитимность, основанная на праве и конституции, перестала быть необходимостью. Параллельно происходит формирование принципов реализации правопреемства от СССР, отбор политических событий, которые могут быть использованы в процессе легитимации политического порядка. Современной власти невыгодно брать на себя ответственность за все происходившее в советский период. Поэтому советское прошлое было ритуально осуждено за сталинские репрессии, ошибки коллективизации, войну в Афганистане и т.д. Однако была проигнорирована противоречивость революции и гражданской войны, превозносится победа в Великой Отечественной войне, при этом отходят на второй план детальное исследование коллаборационизма и страдания народа. Для собственной легитимации власть использует только образ народа-победителя и освободителя Европы во Второй мировой войне. Выборочность исторических событий свидетельствует о том, что конституционно-правовая легитимность в отношении политического порядка сегодня подменяется идеологизированными интерпретациями исторических событий.

Современная Россия не обладает устойчивой формой конституционно-правовой легитимности. Институциональный фундамент государства непрочен, а исторические перспективы зависят от идеологических приоритетов действующей власти. В этой ситуации усложняется процесс самоидентификации политических предпочтений индивидов в обществе. Необходимый базис в виде конституционно-гражданской конструкции, в которой закреплены права и обязанности индивида, дискредитирован в политическом дискурсе и не выполняет качественно институциональную функцию. Альтернативой в отношении гражданской самоидентификации выступают идеологемы и политические мифы, предлагаемый властью идеократический характер управления. С такой позиции идеология апеллирует к надындивидуальным ценностям, подменяя собою демократические принципы конкуренции политических идей в обществе. В рамках идеологической самоидентификации индивид представляется как неотъемлемая часть целого, тогда как в гражданско-правовой - как самостоятельно действующий субъект, носитель ценностного и правового компонента данного общества. Таким образом, можно утверждать, что в российском обществе слабо выражена гражданско-правовая самоидентификация, по-прежнему доминирует патримониальный принцип отношения к государству [Паин, Федюнин 2017].

Процесс формирования легитимности политического порядка имеет определенные катализаторы, позволяющие охарактеризовать существующую систему власти в современной России как продукт традиционалистских и авторитарнобюрократических тенденций. Данная позиция выражена В.П. Макаренко в статье «Но что есть слава и успех» 1 . Нужно различать реальную власть и официальную легитимность, основываясь на тезисе, что ни один государствен-

1 Макаренко В.П. Но что есть слава и успех. - Независимая газета. Доступ: http://www.ng.ru/ stsenarii/2017-09-26/9_7081_instalation.html (проверено 17.02.2019). 
ный институт и само государство не могут быть абсолютно легитимными. Легитимация есть сложный процесс формирования доверия у граждан к власти, иными словами, власть постоянно должна доказывать гражданам свою успешность и необходимость [Макаренко 2018]. Следовательно, сила и успех власти - это абсолютно разные ее характеристики. Решая данное противоречие, власть использует всякие идеологические доктрины, принимает политические решения, подменяя реальное положение дел образами, сформированными положительными процессами, для формирования общественного сознания. В СССР элементы легитимации включали такие средства, как материальные блага, насилие, эффективность власти и привычка, а также апатия населения. Эти аргументы можно рассматривать через элементы авторитарно-бюрократической тенденции русской революции [Макаренко 2013: 181]. К этим элементам относятся: идея достижений и успехов, способность к руководству и патриотизм. Аргументы предстоящего будущего стали одним из основных аргументов оправдания власти и проявляются в трех формах: это светлое будущее, революционная миссия рабочего класса, уверенность в верности выбранного пути развития. Однако ни одна из этих задач не была реализована советской властью, следовательно, это свидетельствует об утопичности реализуемой идеологии и политики и, более того, дискредитирует революционную идею о том, что великая цель оправдывает различные средства, включая насилие, произвол и гражданские конфликты. Следующий аргумент состоит в том, что достижения и успехи эксплуатируются в любой политической системе, которая не поддерживается большинством населения страны. Список достижений советской власти постоянно возрастал, в него входили достижения абсолютно во всех в сферах народного хозяйства, а также международные победы, спортивные достижения и приобщение к благам культуры. Декларирование достижений, различных успехов занимало основное место в выступлениях представителей власти. Следовательно, убеждающая сила различных побед и достижений обладает мнимой идеологической нейтральностью, а в реальности является той же технократической идеологией.

Можно выделить две разновидности легитимации, основанные на достижениях и успехах. Первое - это сравнение существующих достижений с недостатками прошлого. Такая легитимация использовалась советской властью вплоть до 1960-х гг. Параллели для сравнения проводились с экономическими показателями царской России в 1913 г. Второй вид легитимности - сравнение достижений страны с недостатками внешнего мира. Данный вид использовался и продолжает использоваться в сравнении России со странами Запада с присущими ему проблемами безработицы, социальной незащищенности индивида, невозможностью духовно и нравственно развиваться, нарастающими проблемами глобализации. Подобные действия были направлены на дискредитацию западных демократических государств. Немаловажным принципом в этой аргументации было утверждение: «все так делают», который использовался в постсоветской России и позволял легитимировать недостатки любых политических решений и не брать ответственность за принимаемые решения или неудачи в реализации этих решений.

Аргумент патриотической легитимации по мере становления советской власти постоянно возрастал, формируя целый набор вербальных и символических форм. Наиболее используемым принципом было отождествление интересов общества с интересами правительства, государства и идеологии. На основании этого антипатриотическим поведением можно назвать любые выступления против существующего политического и социального порядка, власти, государства и конституционного строя. Это приводит к дискредитации настоящего 
патриотизма, не нуждающегося в государственных программах, концепциях развития и политике воспитания. Таким образом, можно констатировать, что на протяжении существования советской власти произошло смещение акцентов с телеологической легитимации, основанной на достижениях и успехах, а также особой руководящей роли КПСС, к патриотической, этатистской и технократической легитимации, которые используются и современной российской властью.

Подводя итоги, можно утверждать, что вопрос оснований легитимности власти является принципиальным для любого общества. Способы обретения легитимности власти являются продуктом исторического развития государства и социума, включают в себя инструменты политической мобилизации, принципы солидарности и справедливости. Идеологическое прошлое может послужить инструментом изменения оснований легитимности с конституционноправовых форм на идеологические. Отсутствие дискуссионности по принципам и формам достижения легитимности способствует только замещению легитимности идеологией. Любое государство, которое стремится к обоснованию легитимности в одностороннем порядке, не основываясь на солидарности с обществом, формирует идеологизированную систему лжи. Вопрос самоидентификации тесно связан с легитимностью власти. Какую именно легитимность имеет современный политический порядок государства? В этом вопросе приобретает значимость оценка идеологического прошлого, политических традиций и исторической преемственности.

Статья подготовлена при поддержке внутреннего гранта ЮФУ №BнГр-07/2017-27.

\section{Список литературы}

Ассман А. 2014. Длинная тень прошлого: Мемориальная культура и историческая политика. М.: Новое литературное обозрение. 328 с.

Барт Р. 2003. Система Mоды: статьи по семиотике культуры (пер. с фр., вступ. ст. и сост. С.Н. Зенкина). М.: Изд-во им. Сабашниковых. 512 с.

Булдаков В.П., Гудков Л. Д., Зубов А.Б., Пивоваров Ю.С. 2011. Россия на рубежке веков, 1991-2011: сборник. М.: РОССПЭН. 158 с.

Игры на идеологической периферии. Праворадикальные установки студенческой молодежи Ростовской области (под ред. С.П. Поцелуева). 2016. Ростов н/Д: ЮНЦ РАН. 396 с.

Макаренко В.П. 2013. Русская власть и бюрократическое государство. Ростов н/Д.: Март. Ч. 1. 652 с.

Макаренко В.П. 2018. Насилие и политическая бюрократия. Ростов н/Д.: Изд-во Южного федерального университета. 312 с.

Паин Э.А., Федюнин С.Ю. 2017. Нация и демократия: перспективы управления культурным разнообразием. М.: Мысль. 266 с.

Пивоваров Ю.С. 2011. «...И в развалинах век». - Полис. Политические исследования. № 6. С. 52-77.

Поцелуев С.П. Константинов М.С. 2016. Имперский палингенез: праворадикальные идеологемы в студенческой среде (статья первая). - Политика и общество. № 12(144). С. 1608-1619.

Freeden M. 2006. Ideologies and Political Theory: A Conceptual Approach. Oxford: Oxford University Press. 602 p. 
TUPAEV Andrei Vasil'evich, Senior Lecturer at the Chair of Theoretic and Applied Political Science, Southern Federal University (116 Dneprovsky Lane, Rostov-on-Don, Russia, 344090; Bio-412@yandex.ru)

\section{THE IDEOLOGICAL PAST AND THE LEGITIMATION OF THE POLITICAL ORDER: THE EXPERIENCE OF MODERN RUSSIA}

Abstract. The subject of this research is the legitimation of political course in modern Russia based on the use of the ideological past elements. The object of this research is the legitimation forms developed with the ideological past elements, political traditions and myths. The author concludes that the political course of modern Russia renders the legitimation based on historical elements of ideological past, actualized by the power.

Keywords: legitimation, ideology, ideological past, political course, political traditions, power

ПАЛЬЦЕВ Андрей Иванович - кандидат философских наук, доцент; профессор кафедры международных отношений Сибирского института международных отношений и регионоведения (630075, Россия, г. Новосибирск, ул. Народная, 14; Palzew@mail.ru)

\section{СУБЪЕКТНОСТЬ НАЦИИ И ГОСУДАРСТВЕННАЯ БЕЗОПАСНОСТЬ РОССИИ}

Аннотация. В статье рассматривается взаимосвязь между субъектностью нации, определяемой способностью осознавать, ставить и реализовывать собственные цели, являющиеся имманентными ее национальным интересам, и государственной безопасностью, представляющей состояние системы государственного устройства, отвечающее требованиям надежного, эффективного и безопасного функционирования, обеспечивающего жизнедеятельность, развитие и защиту нации. Незавершенность формирования российской нации отчасти является следствием принятия под влиянием американских консультантов ряда законодательных норм, являющихся инструментами концептуального управления. Обретающий субъектность народ ставит через своих представителей в законодательных органах вопрос о создании механизма конституционного определения своего политического статуса. Отсутствие такого механизма может спровоцировать экстремистские элементы в обществе на неконституционные действия, что является прямой угрозой государственной безопасности.

Ключевые слова: субъектность нации, государственная безопасность, концептуальное управление

$\mathrm{M}$ еждународное право не ставит под сомнение внутреннее самоопределение - право народов свободно определять свой политический статус и осуществлять развитие в пределах государства. Принцип равноправия и самоопределения народов трактуется в Декларации ООН следующим образом: «В силу принципа равноправия и самоопределения народов, закрепленного в Уставе Организации Объединенных Наций, все народы имеют право свободно определять без вмешательства извне свой политический статус и осуществлять свое экономическое, социальное и культурное развитие, и каждое государство обязано уважать это право в соответствии с положениями Устава»1.

1 Декларация о принципах международного права, касающихся дружественных отношений и сотрудничества между государствами в соответствии с Уставом Организации Объединенных Наций: принята резолюцией 2625 (XXV) Генеральной Ассамблеи ООН от 24 октября 1970 года. - Официальный сайт ООН. Доступ: http://www.un.org/ru/documents/decl_conv/declarations/intlaw_principles.shtml (проверено 20.01.2019). 